$10 \mathrm{IKC}-246$

\title{
FACTORS CONTROLLING THE INTERNAL FACIES ARCHITECTURE OF KIMBERLITE PIPES
}

\author{
Kurszlaukis, S., Fulop, A. \\ De Beers Canada Inc., Toronto, Canada
}

Under close examination, most if not all kimberlite pipes show a multitude of facies types suggesting that the pipes were emplaced under an episodic reoccurrence of eruptive phases, often with intermittent phases of volcanic quiescence. The majority of these facies can be related to either a change in the fragmentation behavior of the magma during emplacement or are a result of changing conditions during sedimentation of volcaniclastic deposits, as well as their alteration and compaction after deposition.

An additional factor controlling pipe facies architecture is the degree of mobility of the loci of explosions in the explosion chambers of the root zone or root zones at the base of the maardiatreme volcano (Ort and Núñez-Carrasco, 2009). In a growing pipe the root zone moves downwards and with that movement the overlying diatreme enlarges both in size and diameter (Lorenz and Kurszlaukis, 2007). However, during the life span of the volcano, the explosion chamber can also move upwards, back into the lower diatreme, where renewed explosions result in the destruction of older deposits and their structures (White and Ross, 2011).

Next to vertical shifts of explosion chambers, the loci of explosions can also move laterally along the feeder dyke or dyke swarm. This mobility of explosion chambers results in a highly complex facies architecture where a pipe can be comprised of several separate root zones that are overlain by an amalgamated, crosscutting diatreme and maar crater with several lobes.

For our study we are investigating kimberlite pipes of the Jurassic Attawapiskat Kimberlite Field in northern Ontario, Canada. The Field is comprised of 23 known kimberlite pipes, one of which is Victor Mine. Next to Victor, 8 pipes (Bravo-1, Delta-1, India-1, Tango Extension, Whiskey, X-Ray, Yankee and Zulu) were drilled sufficiently in order to understand the internal facies architecture that is controlling diamond distribution within a specific pipe. Victor itself is actually comprised of several pipes (Webb et al., 2004; van Straaten et al., 2009, 2011): Victor Southwest, Southeast and Victor North. The latter occurrence is a product of several amalgamated pipes: Victor Northwest and Victor Main, all of which have a complex internal facies architecture that resulted from the emplacement of different phases of kimberlite over an extended span of time.

During the study of the maar diatreme volcanoes we realized that the facies architecture of a number of pipes showed repetitive patterns. These patterns are not controlled by a change in the nature of the country rocks, since all pipes belong to the same kimberlite field and the country rock strata is a Paleozoic sedimentary cover sequence that had a thickness of about $500 \mathrm{~m}$ at the time of emplacement and that shows very little lateral lithological variation throughout the field. In the case of the Attawapiskat kimberlite pipes, the distribution of volcanic facies within a 


\section{0 $^{\text {th }}$ International Kimberlite Conference, Bangalore - 2012}

kimberlite pipe is rather controlled by the degree of shifting of the explosion chambers and their respective feeder vents during the emplacement history of a pipe. A variation of pipe sizes also allows us to investigate the facies architecture of different structural levels of a pipe, straddling from lower diatreme to deposits that filled the syn- and post-emplacement crater. Hence, our study includes processes that are both primary and resedimented. By having an understanding of the processes, we could also distinguish deposits that were modified in their original structure during the emplacement of younger phases.

The examples from the Jurassic Attawapiskat kimberlite field show that some kimberlite pipes were excavated during initial strong explosions forming several $100 \mathrm{~m}$ deep craters. Towards the end of the emplacement, the eruptive style became less explosive, resulting in a rather low-energy fragmentation behavior of the magma with a very low ability to fragment country rock. During this phase the deep craters are filled with hot pyroclastic deposits that often have a remarkable low content of country rock xenoliths. The final phase of an eruptive cycle is often marked by low-energy spatter fragmentation that produces welded pyroclastic deposits or even lava lakes. Late intrusions of coherent kimberlite sheets into older kimberlite tephra filling the pipe are a common theme in the Attawapiskat kimberlite pipes. This emplacement behavior can be repeated if a new pulse of magma enters the pipe at its bottom. Depending on the time gap in between the ascending kimberlite pulses, older tephra in the pipe is entirely, partly or not at all consoli-dated. In either case mixing of cognate volcaniclastic pyroclasts or juvenile pyroclasts of different nature testify the emplacement of kimberlite within a pipe as repetitive, cyclic events.

It is apparent that these eruptive cycles, from highly explosive to low energy fragmentation and coherent intrusion can be repeated several times during the emplacement of a pipe. Depending on the energy released in a subsequent emplacement cycle, earlier tephra that filled the pipe may be completely ejected, leaving little or even no evidence of its existence. However, if late eruptive cycles start with relative low energy explosions, then earlier tephra in the pipe can survive this event and serves as a witness to earlier volcanic activity in the pipe. Depending on the explosive force position of the explosion chamber in the pipe and vent geometry, the existing tephra becomes variably affected by the renewed volcanic activity.

In steep-sided and small pipes it is rather easy for a subsequent eruption to either fully eject earlier tephra deposits filling the pipe or completely homogenize and mix it. The latter case is indicated by massive deposits and grain-in-grain mixing of different types of juvenile pyroclasts. The Bravo-1 pipe is such an example in the Attawapiskat kimberlite field.

In larger pipes or pipes that are to some extent flaring towards the surface, it is more difficult for a renewed eruption to fully eject earlier tephra from the pipe. The stronger an explosion is the more overlying tephra will be affected. Less energetic explosions will result in eruptions that pierce in the form of a feeder vent through the overlying tephra pile to exit to the surface or, in weak explosions, will not be able to leave the explosion chamber in the root zone or may get stuck in the lower portion of the diatreme as failed tephra jets. In the latter case these weak explosions will still alter the original structure in the lower diatreme, where they destroy bedding and homogenize the pipe infill. These failed tephra jets will mix with the surrounding tephra already filling the pipe and may, in some cases, be still traceable by their diagnostic petrographic features and variations in diamond content.

If the explosion sites in the root zone are laterally immobile then older deposits, which were originally forming mostly horizontal layers on the respective crater floors, become tilted and down rafted towards the centre of the pipe. This is firstly a function of simple compaction of the tephra, 


\section{0 $^{\text {th }}$ International Kimberlite Conference, Bangalore - 2012}

which will be more pronounced in the central portion of a pipe due to its larger depth extent of the underlying tephra column compared to the margins of the pipe. In addition, the consumption of existing tephra in the lower portion of a pipe due to renewed eruptions originating in the root zone also causes tilting and down rafting of formerly horizontal beds towards the deep central part of a kimberlite pipe.

This cyclic emplacement behavior combined with tilting due to compaction and down rafting forms an internal symmetric facies architecture with a cone-in-cone like arrangement of volcanic deposits. The Victor NW pipe is an example where these emplacement sequences are repeated over time.

Vertical shifts of the explosion sites within the root zone can also add complexity to the internal pipe architecture. Pipe growth occurs when the explosion chambers move downwards and the overlying diatreme expands both towards depth and laterally. In basaltic maar-diatreme volcanoes this continuous downward growth process is typically achieved when a vertical hydrologically active fault is cut by the feeder dyke of the volcano resulting in thermohydraulic explosions. In the Attawapiskat area the hydrological situation is different in that groundwater is not only restricted to (sub-) vertical faults and joints, but is also fed from strata bound artesian aquifers which occur in certain levels of the Paleozoic siliciclastic and limestone country rock sequence. These aquifers seem to have played a major role in the emplacement behavior of the Attawa-piskat kimberlite pipes. The Delta kimberlite pipe, for example, shows a step-wise, but incomplete, growth process where the explosion site was moving from one aquifer to the next deeper one. When magma supply into the root zone ceased the pipe growth process was terminated in a juvenile stage, leading to downward sagging of large amounts of brecciated local country rock material instead of developing an entirely tephra-filled, well-mixed pipe.
If the explosion sites are stagnant, for example due to the strong influx of external water from an aquifer into the root zone, then the ongoing explosions will widen the root zone. The wider a root zone the less impact an explosion has on the country rocks, since the root zone is filled by down sagged kimberlite tephra. Hence these explosions will not further grow the pipe by the excavation of country rock but will rather mix and recycle tephra of the overlying diatreme with newly fragmented tephra from kimberlite intruding the bottom of the root zone. This scenario of a stagnant root zone leads to a pipe that flares upwards from the bottom of the pipe with a tephra infill that is typically low in xenolith content and is highly homogenous in nature. Victor Main, which is to some extent flaring from an artesian aquifer at the interface between basement and overlying Paleozoic sediments, is an example for such a pipe.

If aquifers or hydrologically active faults become depleted during volcanic activity, intruding magma can pass the site of earlier fragmentation and forms intrusive sheets higher within the diatreme or forms spatter that may reconstitute to lava on the maar crater floor (as seen in Victor NW, Delta and India kimberlite pipes). Magma can also explode again in higher levels of the pipe if shallow aquifers or faults are recharged by reflux from surface water. This vertical upward movement of the explosion sites will also affect the internal facies architecture, in that it will destroy all previous structure in the surrounding area and mix and homogenize it.

Next to vertical shifts of the explosion chambers in a root zone, the root zone can also move laterally during pipe emplacement. This occurs either along the feeder dyke, hydrologically active faults or zones of preferred weakness in the country rock. As a result a kimberlite pipe can become a complex amalgamation of a number of different individual pipes with slightly offset root zones that may separate at depth. Depending on whether the lateral movement of the root zone is 


\section{0 $^{\text {th }}$ International Kimberlite Conference, Bangalore - 2012}

unidirectional, an oval shaped or elongated pipe at surface is the consequence. If a pipe is fed from a set of feeder dykes or grows both in the direction of the feeder dyke and towards a hydrologically active fault, then a complex crosscutting relationship of individual but amalgamated pipes can be generated. Naturally, the internal geology of these pipes can be extremely complex, especially if there are no time gaps in between the emplacement of the individual pipes and the contact between them is masked and altered by mixing processes. If the plumbing system underneath such a volcanic complex is re-used after a time gap, the older emplaced maar-diatreme volcanoes may be partially or fully consolidated and clearer crosscutting relationships may prevail. A volcanic pipe that shows both evidence of consolidation and mixing of loose tephra is Victor North. The interface between Victor NW and Victor Main (which comprise Victor North) is sharp and steep, suggesting a time gap sufficiently long for consolidation of the older tephra fill, in between these two amalgamated volcanoes. However, diamond grade changes within Victor Main ore suggests mixing of different grade magma batches with very similar petrographic features.

While lateral and vertical migration of explosion sites changes the primary internal facies distribution in a pipe, crater infill processes also contribute significantly to the architecture of a maar-diatreme volcano. Pipe infilling deposits record a sequence of explosive and emplacement events suggesting a multistage infill of the volcanic crater. The excavation of the pipe through high-energy explosions produces a deep maar crater that initially can be several hundred meters deep. The walls of this juvenile maar crater are over steepened and unstable and have thus high relief energy. En masse resedimen-tation processes prevail during pipe emplacement and immediately after eruptions cease or become weaker. Hence the first sediments deposited on a post-eruptive crater floor are often the result of mass movements that show the whole spectrum of cohesive to diluted mass flows: debris flows, hyperconcentrated flows and grain flows to turbidity currents mixed or interlayered with kimberlite tephra from the maar crater rim. These gravitational collapse events fill the crater quickly and will also decrease the angle of the still exposed maar crater, resulting in an increasingly shallow but wider, mature crater. The widening of the crater has the consequence that increasingly less and finer kimberlite tephra sourced from the more distal tephra ring will be resedimented into the crater, and low energy sedimentary processes become more dominant due to the incremental reduction of relief energy.

Since most maar craters cut into the groundwater table, the crater fill quickly with water and a crater lake will develop. Ongoing explosions through lake sediments will lead to the collapse of the vent wall by slides/slumps and mud flows. Sorting processes will show significant differences in between coarse grained deposits proximal to the pipe wall and finer grained deposits in central area of the crater.

Many of the Attawapiskat pipes show all signs of high relief energy juvenile craters and craters that are synchronously in-filled by both primary and resedimentation processes. Due to the estimated erosion of $200 \mathrm{~m}$ since emplacement (pers. Comm. F. Brunton), only Tango Extension shows features typical of low relief energy, mature craters.

\section{References}

Lorenz, V. and Kurszlaukis, S., 2007. Root zone processes in the phreatomagmatic pipe emplacement model and consequences for the evolution of maar-diatreme volcanoes. Journal of Volcanology and Geothermal Research, 159, 4-32.

Ort, M.H. and Núñez-Carrasco, G., 2009. Lateral vent migration during phreatomagmatic and magmatic eruptions at Tecuitlapa Maar, east-central Mexico. Journal of Volcanology Geothermal Research, 181, 67-77. 


\section{0 $^{\text {th }}$ International Kimberlite Conference, Bangalore - 2012}

van Straaten, B.I., Kopylova, M.G., Russell, J.K, Webb, K.J and Scott Smith, B.H., 2009. Stratigraphy of the intra-crater volcaniclastic deposits of the Victor Northwest kimberlite, northern Ontario, Canada. Lithos, 1125, 488-500.

van Straaten, B.I., Kopylova, M.G., Russell, K.J and Scott Smith, B.H., 2011. A rare occurrence of a crater-filling clastogenic extrusive coherent kimberlite, Victor Northwest (Ontario, Canada). Bulletin of Volcanology, DOI 10.1007/s00445-0110507-7.
Webb, K.J., Scott-Smith, B.H., Paul, J.L. and Hetman, C.M., 2004. Geology of the Victor Kimberlite: cross-cutting and nested craters, Attawapiskat, Northern Ontario, Canada. Lithos, 76 (1-4), 2950.

White, J.D.L and Ross, P.-S., 2011. Maar-diatreme volcanoes: A review. Journal of Volcanology and Geothermal Research, 201 (1-4), 1-29. 